\title{
Cultural Processes and Teacher-Educators' Technology Knowledge and Skills at Makerere University
}

\author{
David Kakeeto $^{1}$, Anthony Muwagga Mugagga ${ }^{2}$, Ronald Bisaso $^{3}$ \\ ${ }^{1}$ Lecturer, Department of Computing and Information Science, Nkumba University. Kampala Uganda \\ ${ }^{2}$ Senior Lecturer, School of Education, College of Education and External Studies, Makerere University. \\ Kampala Uganda \\ ${ }^{3}$ Dean, The East African School of Higher Education Studies and Development (EASHESD), College \\ of Education and External Studies, Makerere University. Kampala Uganda \\ Email: dkakeeto@gmail.com
}

\begin{abstract}
The study was set out to examine the influence of cultural processes on teacher educators' digital competence at School of Education, Makerere University, and Kampala Uganda. A case study design was employed taking a quantitative approach. Objectives of the study were to establish how individual and institutional values influence teacher educators' technology knowledge and skills at Makerere University. Participants were teacher trainers from School of Education and data were collected using a self administered questionnaire. Data were analyzed using; ANOVA, Pearson Product moment Correlation coefficient and Regression. It was found out that: both individual and institutional values have got a significant positive influence to teacher educators' technology knowledge and skills. It was concluded that; individual values in form of: level of education, teaching experience, attitude or belief and disciplinary background are very fundamental in promoting teacher educators' technology skills and knowledge; institutional values in form of: leadership styles, policy guidelines, curriculum and structural facilities are critical aspects in promoting teacher educators' technology knowledge and skills. It was recommended that The School of Education should develop an evaluative instrument to regularly assess the extent to which ICTs have promoted teaching and learning, University administrators should change their leadership styles, adopt transformational leadership style according because results indicated that it promotes teacher educators' technology knowledge and skills

Keywords: individual values; institutional values; technology skills and technology knowledge
\end{abstract}

\section{Introduction}

Cultural processes have been anticipated to have influence on teacher-educators' technology skills and knowledge. These Cultural processes were looked at as individual or institutional behaviors, aspects or structural facilities which shape the essential nature and presence of individual (s) in a certain community of learning.

Institutional or organizational culture according to Edward \& Calen (2020) is a characteristic that is highly invested by the organization and is an example of an organization to distinguish between one organization and another. These farther argue that, organizational culture contains the values and norms of behavior that are accepted and understood together by members of the organization as a basis for the provisions of the behavior that exists within the organization. Thus, organizational culture can influence the way employees work and behave in the organization. If employees can accept both the organizational culture that is applied, then it can make employees work with comfortable, energetic, and try harder to work to improve performance. 
Pedagogical innovations around the globe have been explored using information and communication technology and a number of reforms have been driven by theories of human learning and development, such as social constructivism which emphasizes the culture and social aspects of human learning through interactions (Martinez-Garcia et al., 2012). This study was based on Social Constructivism which has emerged as one of the greatest influences on the practice of education in the 21 st century. The theory looks at learning as an active process, taking students' prior knowledge into consideration, building on preconceptions, and eliciting cognitive conflict. Whereas several projects such as; Blackboard and MUELE learning management systems have been adopted to facilitate ICT-based teaching and learning at Makerere University, little has been attained in School of Education, Makerere University and yet this is a very big teacher-training center in the Country and region at large. Hence there was need to establish how cultural processes both institutional and individual values have influenced teacher educators' technology knowledge and skills at Makerere University.

Objectives

1. Establish how individual values influence teacher educators' technology knowledge and skills at Makerere University.

2. Establish how institutional values influence teacher educators' technology knowledge and skills at Makerere University.

\section{Review of Literatures}

\subsection{Individual Values and Technology Knowledge and Skills}

These individual values included: level of education, teaching experience, attitude or belief and disciplinary background. According to Yusuf (2005) in Boakye (2013), teaching experience was found to influence the use of technologies by lecturers in teaching. It is assumed that, lecturers' willingness to apply technologies in teaching increases with increasing teaching experience. Similarly, teaching experience is said to increase with effectiveness of teaching using technology (Win, 2002) in Boakye (2013). Again Win (2002) found out that, lecturers' level of education influences their ability to teach using technologies. In the same line, Teo (2012) also reported that, attitude, behavioural controls and self-efficacy are very likely to influence teachers' adoption and use of ICTs in teaching. Similarly, Buabeng-Andoh (2012 b) mention that success of an educational technology programme in any institution depends on the teachers' support, and their attitudes as well as the beliefs they hold about the potentials of a particular technology in transforming their teaching practice.

Accordingly, Edward, Y. R., \& Calen. (2020) explain that, organizational culture it can be concluded that organizational culture is a value system that is believed and adhered to by members of the organization that can influence the behavior of members in the organization. Then, Chai, Koh and Tsai (2010) in Shan (2013) investigated pre-service teachers' beliefs about the use of computer technology and the effectiveness of ICT courses. Their results indicated that after participating in courses, pre-service teachers recognized the importance of technology integration into their curricula and believed that ICT use would enhance student learning. In Shan (2013) Pelgrum and Law (2009) reported that effective ICT integration depends on the perceptions and vision of school leaders rather than teachers' ICT skills. School or institutional culture has a mediating role that influences teachers' actions, beliefs, and attitudes. However, Tezci (2011b) in Shan (2013) also examined Turkish teacher perceptions about ICT integration and results showed that teachers' perceptions were not positive, because the majority did not believe that they would receive adequate technical and 
motivational support from their school. Although, as the school culture became more positive, the teachers' ICT usage level increased.

According to Oxford English Dictionary, an academic discipline is a branch of learning or scholarly instruction. It is presumed that; subject specialty influences teacher's ability to uptake or abandon technology integration (technology knowledge and skills). According to Win (2002) in Boakye (2013), lecturers of science-related subjects are more willing to apply technologies in teaching than lecturers of arts-related subjects. Czerniewicz \& Brown (2007) found out that there are significant differences in the way these different academic disciplines are taught and so there are different teaching approaches adopted, hence various information technology applications adopted.

\subsection{Institutional Values and Technology Knowledge and Skills}

The study evaluated institutional culture of Makerere University in line with teacher educators' technology skills and knowledge. Institutional values included: leadership styles, policy guidelines, curriculum and structural facilities. Tezci (2011) reported that, school culture has a key role the development of ICT knowledge and skills. Technology integration process in teaching requires institutional support, the teacher trainers and trainees need to be supported to develop their technical knowledge. However, Phillips, Proshad, Campbell, \& Phillips (2020) argue that, throughout history, culture has been an influence on the way people think and behave and learn. It is obvious that cultural differences influence people's cognitive process, however, despite the way people perceive things are according to culture and there are many differences, there are also some similarities and the way in which information is being processed seems to be the same among cultures.

Authoritative leadership: Shamaki (2015) reveals that, employees under this leadership style work under pressure and fear which may negatively affect their ability of innovativeness. $\mathrm{Wu}$ and Shiu (2009) found out that, this leadership style is full of punishment, threat, demands, orders, rules, and regulations. However, because authoritarian leaders are goal seekers as Bush (2011) contend, they emphasize goal achievement by keeping staff focused on tasks to be accomplished, no room for innovation. Whereas Distributed leadership focuses on an open environment, where top management works hand in hand with lower managers for example; College decisions involve not only the College Principal, but also the Deans and Heads of Department. Clark (2007) also reports that distributed leadership is characterized by consultation, empowerment, joint decision making and power sharing. Sloan (2013) found out that, distributed leadership as an important element in developing an inquiry versus compliance orientation to ICT integration. Transactional leadership: is a process of exchange of transactions between the leaders and the followers (North house, 2007).

Kashagate (2013) found out that, a university leadership which employs transactional leadership is less likely to inspire its employees in adoption of new skills and knowledge. In Adeyemi's (2010) study however, the performance of teacher trainers was found to be better in institutions which have got administrators who use autocratic leadership style. Transformational leadership: Aunga \& Masare (2017) revealed a direct and positive connection between transformational leadership style and teachers' performance. Kashagate (2013) also found a positive correlation between transformational leadership dimensions and teachers' performance. Bateh and Heyliger (2014) reported that, faculty members who identified transformational leadership as dominant had increased performance, hence high adoption ability. Again Singh (2015) found out that transformational leaders have a significant influence on achievement of goals by fostering trust and building relationship with subordinates. Kovjanic et al (2013) reveals that transformational leaders influence positively 
towards employee performance in terms of work engagement, quality, quantity and persistence and innovation.

\subsection{Curriculum Design and Technology Knowledge and Skills}

Teachers around the world today are taking a skills-based approach to education to prepare students to build careers and be active citizens after completing school (Sahlberg, 2010). Preparing teachers today to meet future challenges is a major mission of higher education in Uganda, so that the children are brought up as knowledge creators not merely consumers. Faculties, departments or colleges have considerable autonomy over curriculum issues and the process of teaching and learning (Bergquist \& Pawlak, 2008). So, the way a curriculum is designed and developed must clearly indicate the pedagogical aspects of ICT integration. Tosun \& Barişusing (2011:223) believed that universities which want to reposition themselves in the market, they must have a strategic plan which clearly indicates how technology integration should be done. Ling (2014) reveals that, among the Educational reforms today involve is pedagogical innovations which involve ICT integration so as to reduce teacher-dominated pedagogy and also to minimize examination-oriented knowledge transmission which does not cultivate students' critical thinking and problem solving skills.

\subsection{Policy Guidelines}

Institutional policies must be aimed at improving performance in the different aspects of service. Aguti (2016) emphasizes the need to have appropriate policies and policy environments that support transformation, creativity and innovation. Accordingly, UNESCO $(2000 ; 2012)$ also at the international level, policy for integrating ICT for development was first formulated in the Millennium Development Goals (MDGs). Gregor, Dalgarno, \& Gray (2010) indicated that, the limited use of educational technologies in university teaching is due to limitations in national and institutional policies and management practices about ICT integration. Mkaerere University ICT policy (2016 - 2020, page 6) emphasizes integration of ICT in teaching and learning, but unfortunately it does not indicate how the entire innovation should be implemented.

\section{Hypothesis}

H1: Individual values influence teacher-educators' technology knowledge and skills at Makerere University.

H1: Institutional values influence teacher-educators' technology knowledge and skills at Makerere University.

\section{Research Methods}

\subsection{Research Design}

The research adopted a case study design applying a quantitative approach, and a correlational design involving use of a Likert scaled Self administered questionnaire.

\subsection{Participants}

The researcher targeted teacher trainers in the School of Education, College of Education and External studies, Makerere University and out of the 64 academic staff, only 37 were accessible, but the actual sample size was 26 participants from three departments: Humanities and Language Education, Science, Technical and Vocational Education plus the Foundation and Curriculum Studies, stratified and simple random sampling techniques were applied. 


\subsection{Data Collection Instruments}

Since the study was quantitative, a self administered questionnaire was used to collect data from the participants. The questionnaire basically was composed of four sections; background variables, the dependent (digital competence) and two independent variables (individual and institutional values).

\subsection{Data Analysis}

Data were subjected to a quantitative analysis at both univariate and bivariate levels. At univariate level, frequency counts and summary statistics were used while at the bivariate level; ANOVA and Correlation Analysis using Pearson's product Moment Correlation and regression analysis methods were applied.

\section{Results and Discussion}

\subsection{Results}

\section{a. Description of the Dependent Variable: Digital Competence}

This Section gives a description of the dependent variable (Digital competence) which was looked at as; technology knowledge and skills were conceptualized using ten test items which required each respondent to do self-rating on digital competence levels and the results were as indicated below;

Table 1. Descriptive Statistics on Teacher Educators' Digital Competence

\begin{tabular}{|l|r|r|r|r|r|}
\hline Test items & N & Min. & Max. & Mean & Std. Dev. \\
\hline $\begin{array}{l}\text { ICT in education has changed the way I work } \\
\text { in my classroom through improved } \\
\text { communication }\end{array}$ & 26 & 1.00 & 5.00 & 3.5000 & 1.67929 \\
\hline $\begin{array}{l}\text { Using ICT in education has facilitated my } \\
\text { teaching through content creation. }\end{array}$ & 26 & 1.00 & 5.00 & 3.6538 & 1.32491 \\
\hline $\begin{array}{l}\text { ICT in education has contributed to } \\
\text { cooperation between me and my students in } \\
\text { terms information sharing. }\end{array}$ & 26 & 1.00 & 5.00 & 4.0000 & 1.20000 \\
\hline $\begin{array}{l}\text { Using ICT teaching has made students more } \\
\text { active and promotes problem-based learning }\end{array}$ & 26 & 1.00 & 5.00 & 3.2692 & 1.34336 \\
\hline $\begin{array}{l}\text { Using ICT in teaching has increased students' } \\
\text { awareness in a range of themes and promotes } \\
\text { creativity. }\end{array}$ & 26 & 1.00 & 5.00 & 3.5769 & 1.23849 \\
\hline $\begin{array}{l}\text { ICT in education makes teaching and } \\
\text { learning funnier because of the continued } \\
\text { collaborations amongst teachers and students }\end{array}$ & 26 & 3.00 & 5.00 & 4.4231 & .70274 \\
\hline $\begin{array}{l}\text { ICT in education prepares students for their } \\
\text { future career in the digital era. }\end{array}$ & 26 & 2.00 & 5.00 & 4.4615 & .70602 \\
\hline $\begin{array}{l}\text { ICT in education is important in order to } \\
\text { prepare students to be active members of the } \\
\text { public }\end{array}$ & 26 & 2.00 & 5.00 & 3.8846 & 1.03255 \\
\hline $\begin{array}{l}\text { ICT in education develops teachers } \\
\text { pedagogical ability from teacher centered to } \\
\text { learner centered approach. }\end{array}$ & 26 & 1.00 & 5.00 & 4.3846 & .85215 \\
\hline
\end{tabular}




\begin{tabular}{|l|r|r|r|r|r|}
\hline $\begin{array}{l}\text { Teacher trainers should have ICT knowledge } \\
\text { and skills in order to support learners' ability } \\
\text { to construct knowledge. }\end{array}$ & 26 & 4.00 & 5.00 & 4.8846 & .32581 \\
\hline Valid N (listwise) & 26 & & & & \\
\hline
\end{tabular}

Source: Primary data, 2019

Basing on study results on the dependent variable (Digital competence) which was looked at in form of technology knowledge and skills, respondents agreed to the following responses as indicated by the mean values: ICT in education has changed the way I work in my classroom through improved communication, mean value $=3.50$. This shows that, many teacher educators have at least used ICT to some extent to support their teaching especially in creating content as also indicated in following statement; Using ICT in education has facilitated my teaching through content creation, mean $=3.65$; ICT in education has contributed to cooperation between me and my students in terms information sharing, mean $=4.00$. There is no doubt that use of ICT in teaching promotes learner collaboration; Using ICT in teaching has increased students' awareness in a range of themes and promotes creativity, mean $=3.57$; ICT in education makes teaching and learning funnier because of the continued collaborations amongst teachers and students, mean $=4.42$; ICT in education prepares students for their future career in the digital era, mean $=4.46$; ICT in education is important in order to prepare students to be active members of the public, mean $=3.88$; ICT in education develops teachers' pedagogical ability from teacher centered to learner centered approach, mean $=4.38$; Teacher trainers should have ICT knowledge and skills in order to support learners' ability to construct knowledge, mean score $=4.88$. All the above responses do indicate that technology knowledge and skills are fundamental in promoting technology integration in teacher training. There was only one test item, "Using ICT teaching has made students more active and promotes problem-based learning" which received mean value = 3.26, indicating that the participants were not so sure whether the student teachers were more active and had the ability solve problem-based learning. May be learners have not fully exhibited their technology skills and knowledge since many of their tutors have also failed up to explore these technologies to support their teaching.

For purposes of finding out whether cultural processes affect teacher educators' digital competence, all items on this Section of the Questionnaire of the dependent variable (digital competence $=$ technology knowledge and skills) were aggregated in one index and named it, "DigComp" which is an acronym for digital competence.

\section{b. Variations of Teacher Educators' Digital Competence with Department}

The study was interested in finding out whether digital competence varied with department. Table 2 shows related ANOVA results;

Table 2. Variations of Teacher Educators' Digital Competence with Department

\begin{tabular}{|c|c|c|c|c|c|c|c|}
\hline & $\mathbf{N}$ & Mean & $\begin{array}{l}\text { Std. } \\
\text { Dev. }\end{array}$ & Min. & Max & $\mathbf{F}$ & Sig. \\
\hline $\begin{array}{l}\text { Humanities and Language } \\
\text { Education }\end{array}$ & 15 & 35.800 & 4.97422 & 30.00 & 44.00 & \multirow[t]{4}{*}{17.630} & \multirow[t]{4}{*}{.000} \\
\hline $\begin{array}{l}\text { Science, Technical and } \\
\text { Vocational Education }\end{array}$ & 5 & 43.400 & 3.97492 & 37.00 & 48.00 & & \\
\hline $\begin{array}{l}\text { Foundation and Curriculum } \\
\text { Studies }\end{array}$ & 6 & 47.833 & 2.85774 & 42.00 & 49.00 & & \\
\hline Total & 26 & 40.038 & 6.75562 & 30.00 & 49.00 & & \\
\hline
\end{tabular}

Source: Primary data, 2019 
The mean values in Table 2 suggest that there are variations in digital competence amongst the three Departments in the School of Education, College of Education and External Studies, Makerere University as follows: Foundation and Curriculum Studies had the highest mean value of 47.833 , which implies these teacher trainers had better adoption levels of technology skills and knowledge, this could be attributed to the fact that, curriculum studies involve development of teaching aids, and ICT has the most modern and suitable teaching aids, like use of simulations and animations which lecturers adopt in managing courses like educational technology. This was followed by Science,

Technical and Vocational Education with mean value of 43.400, and this could be attributed to the fact that science subjects are more practical in nature and thus the application of technology in teaching is more feasible. Humanities and Language Education had the lowest mean value of 35.800 which is far lower compared to the other two Departments. However, this could be attributed to the fact that, many teacher educators in Humanities still need to be guided to practically handle their curriculum, subjects like; Economics, Geography and Religious studies need to be redesigned especially the teaching approaches so that, the practical elements can be brought on board, hence integrate ICT in its practical sense. The teacher trainers in Humanities seem to have little computerized content as compared to their counterparts in Curriculum and Science Departments. To verify these variations, the researcher computed for the Analysis of Variance (ANOVA) and the results were as follows; F-value obtained is $\mathbf{1 7 . 6 3 0}$, whose significance (sig) value $\mathbf{p}=\mathbf{0} . \mathbf{0 0 0}$ which is less than $\alpha=$ 0.05. Hence results indicate that there is a significant difference in terms of technology skills and knowledge between the three Departments in The School of Education.

\section{c. Variations of Teacher Educators' Digital Competence with Teaching Experience}

The study was interested in finding out whether digital competence varied with teaching experience. Table 3 shows related ANOVA results;

Table 3. Variations of Teacher Educators' Digital Competence with Teaching Experience

\begin{tabular}{|c|c|c|c|c|c|c|c|}
\hline & $\mathbf{N}$ & Mean & $\begin{array}{l}\text { Std. } \\
\text { Dev. }\end{array}$ & Min. & Max. & F & Sig. \\
\hline Less than 5 years & 3 & 44.0000 & .00000 & 44.00 & 44.00 & \multirow[t]{5}{*}{3.469} & \multirow[t]{5}{*}{.033} \\
\hline Between 5 and 10 years & 12 & 40.8333 & 6.68558 & 32.00 & 49.00 & & \\
\hline $\begin{array}{l}\text { Between } 10 \text { and } 15 \\
\text { years }\end{array}$ & 8 & 41.1250 & 6.35694 & 33.00 & 49.00 & & \\
\hline More than 20 years & 3 & 30.0000 & .00000 & 30.00 & 30.00 & & \\
\hline Total & 26 & 40.0385 & 6.75562 & 30.00 & 49.00 & & \\
\hline
\end{tabular}

Source: Primary data, 2019

The mean values in Table 3 suggest that there are variations in technology knowledge and skills of lecturers in line with their teaching experience in such a way that; teacher trainers who have spent more than twenty years at the University seem to have low technology knowledge and skills (mean $=30.00)$ as compared to their counterparts who have spent less than twenty years in the University service (mean value almost $=42$ ). This could be explained by the fact that, technology integration in the University is a new phenomenon whereby, its adoption and use has been more common with current generation. To verify these variations, the researcher computed for the Analysis of Variance (ANOVA) and the results were as follows; F value obtained is 3.469, whose significance (sig) value of $\mathbf{0 3 3}$ which is less than $\boldsymbol{\alpha}$ $=0.05$. Hence these results indicate that there is significant difference teacher educators' digital competence and teaching experience in The School of Education. However, these differences may not necessarily reflect more experienced individuals with more digital skills, 
because, teacher educators who have been in the University service for less than 15 years show higher levels of digital skills than teacher educators who have served for over 20 years. This could be attributed to the fact that, most of these lecturers who have spent less time in teaching are the young generation and therefore more digital compliant, more adoptive, still very dynamic compared to their counterparts who have stayed in the University for more than 20 years.

\section{d. Variations of 'Teacher Educators' Digital Competence with Academic Discipline}

The study was interested in finding out whether digital competence varied with teacher educators' academic discipline. Table 4 shows related ANOVA results;

Table 4. Variations of Teacher Educators' Digital Competence with Academic Discipline

\begin{tabular}{|c|c|c|c|c|c|c|c|}
\hline Subject/discipline & $\mathbf{N}$ & Mean & Std. Dev. & Min. & Max. & $\mathbf{F}$ & Sig. \\
\hline Mathematics & 2 & 46.0000 & 2.82843 & 44.00 & 48.00 & \multirow[t]{15}{*}{2.728} & \multirow[t]{15}{*}{.046} \\
\hline Physics & 1 & 44.0000 & & 44.00 & 44.00 & & \\
\hline Chemistry & 2 & 40.5000 & 4.94975 & 37.00 & 44.00 & & \\
\hline Luganda Language & 3 & 38.6667 & 6.11010 & 32.00 & 44.00 & & \\
\hline English Language & 2 & 44.0000 & .00000 & 44.00 & 44.00 & & \\
\hline Geography & 1 & 35.0000 & & 35.00 & 35.00 & & \\
\hline Educational Technology & 2 & 45.5000 & 4.94975 & 42.00 & 49.00 & & \\
\hline Curriculum Studies & 5 & 46.2000 & 6.26099 & 35.00 & 49.00 & & \\
\hline Economics & 2 & 30.0000 & .00000 & 30.00 & 30.00 & & \\
\hline Language pedagogy & 1 & 33.0000 & & 33.00 & 33.00 & & \\
\hline History & 1 & 30.0000 & & 30.00 & 30.00 & & \\
\hline Religious studies & 2 & 35.0000 & .00000 & 35.00 & 35.00 & & \\
\hline Music & 1 & 35.0000 & & 35.00 & 35.00 & & \\
\hline Art and Design & 1 & 35.0000 & & 35.00 & 35.00 & & \\
\hline Total & 26 & 40.0385 & 6.75562 & 30.00 & 49.00 & & \\
\hline
\end{tabular}

\section{Source: Primary data, 2019}

The mean values from Table 4 suggest that there are differences in digital competence from the disciplinary point of view, i.e. discipline priorities and needs dictate the application of ICT in teaching and learning. For example, Mathematics and physics respectively (mean = 46.00 and 44.00) these are hard pure subjects as compared to other subjects like: Economics and History each with (mean $=30.00$ ) which are soft pure. So there is a difference in technology knowledge and skills between subjects/academic disciplines amongst the teacher trainers in Hard pure and Soft pure discipline. ANOVA results are as follows: $\mathbf{F}$ value obtained is 2.728, whose significance (sig) value of $\mathbf{. 0 4 6}$ which is less than $\boldsymbol{\alpha}=\mathbf{0 . 0 5}$. Discipline priorities and needs dictate the application of ICT in teaching, whereby hard pure exhibited more digital competence (mathematics with mean value 46; physics mean value $=44$ etc. as compared to soft pure (economics with mean value $=30$; History $=30$ etc.). Curriculum studies and educational technology had higher mean values too that is; 46.2 and 45.5 respectively, but these are not academic disciplines, they can apply to hard pure or soft pure.

\section{d. Verification of Hypothesis One}

The first hypothesis was stated that, $\mathbf{H}_{1}$ : "individual values influence teacher-educators technology knowledge and skills in teaching at Makerere University". 
Table 5. Pearson's Correlation Co-efficient for Individual Values and Teacher Educators' Digital Competence

\begin{tabular}{|c|c|c|c|}
\hline \multicolumn{4}{|c|}{ Correlations } \\
\hline & & $\begin{array}{c}\text { Individual values } \\
\text { (INDIVAL) }\end{array}$ & $\begin{array}{c}\text { Digital Competence } \\
\text { (DIGCOMP) }\end{array}$ \\
\hline \multirow{3}{*}{ Individual values } & $\begin{array}{l}\text { Pearson } \\
\text { Correlation }\end{array}$ & 1 & $.587^{* *}$ \\
\hline & Sig. (2-tailed) & & .002 \\
\hline & $\mathrm{N}$ & 26 & 26 \\
\hline \multirow{3}{*}{ Digital Competence } & $\begin{array}{l}\text { Pearson } \\
\text { Correlation }\end{array}$ & $\mathrm{r}=.587^{* *}$ & 1 \\
\hline & Sig. (2-tailed) & $\mathrm{p}=.002$ & \\
\hline & $\mathrm{N}$ & 26 & 26 \\
\hline
\end{tabular}

Table 5 shows that, Pearson's Correlation Coefficient for individual values (INDIVAL) and digital competence (DIGCOMP), was $\mathbf{r}=\mathbf{0 . 5 8 7}$, which was positive with probability value $(\mathrm{p}=\mathbf{0 . 0 0 2})$ less than $\boldsymbol{\alpha}=\mathbf{0 . 0 1}$ suggesting a significant correlation, implying that individual values significantly positively correlated with teacher educators' digital competence at Makerere University at the one percent level of significance.

\section{e. Verification of Hypothesis Two}

The second alternative hypothesis was stated that, $\mathbf{H}_{1}$ : "Institutional values influence teacher-educators technology knowledge and skills in teaching at Makerere University".

Table 6. Pearson's Correlation Co-efficient for Institutional Values and Teacher Educators' Digital Competence

\begin{tabular}{|c|c|c|c|}
\hline \multicolumn{4}{|c|}{ Correlations } \\
\hline & & $\begin{array}{l}\text { Institutional values } \\
\text { (INSTIVAL) }\end{array}$ & $\begin{array}{c}\text { Digital } \\
\text { Competence } \\
\text { (DIGCOMP) }\end{array}$ \\
\hline \multirow{3}{*}{ Institutional values } & $\begin{array}{l}\text { Pearson } \\
\text { Correlation }\end{array}$ & 1 & $.778^{* *}$ \\
\hline & Sig. (2-tailed) & & .000 \\
\hline & $\mathrm{N}$ & 26 & 26 \\
\hline \multirow{3}{*}{ Digital Competence } & $\begin{array}{l}\text { Pearson } \\
\text { Correlation }\end{array}$ & $\mathrm{r}=.778^{* *}$ & 1 \\
\hline & Sig. (2-tailed) & $p=.000$ & \\
\hline & $\mathrm{N}$ & 26 & 26 \\
\hline
\end{tabular}

Table 6 shows that, Pearson's Correlation Coefficient for institutional values (INSTIVAL) and digital competence (DIGCOMP), was $\mathbf{r}=\mathbf{0 . 7 7 8}$, which was positive with probability value $(\mathrm{p}=\mathbf{0 . 0 0 0})$ less than $\boldsymbol{\alpha}=\mathbf{0 . 0 1}$ suggesting a significant correlation, implying that institutional values significantly positively correlated with teacher educators' digital competence at Makerere University at the one percent level of significance. Therefore, institutional values such as curriculum, policies, ICT structures and Leadership styles have a very major influence on teacher educators' ability to use ICTs in teaching and learning. 


\section{f. Regression Analysis}

For purposes of indicating which of the two independent variables, that is; individual and institutional values influences digital competence (dependent variable) most, the researcher had to compute for regression.

Table 7. Regression Analysis for Individual and Institutional Values vs. Digital Competence

\begin{tabular}{|c|c|c|c|c|c|}
\hline $\begin{array}{l}\text { Predictor } \\
\text { variable }\end{array}$ & Model & Sum of Squares & R Square & $\mathbf{F}$ & Sig. \\
\hline \multirow[t]{3}{*}{ Individual values } & Regression-a & 392.917 & .344 & 12.606 & $.002^{\mathrm{b}}$ \\
\hline & Residual & 748.045 & & & \\
\hline & Total & 1140.962 & & & \\
\hline \multirow{3}{*}{$\begin{array}{l}\text { Institutional } \\
\text { values }\end{array}$} & Regression-b & 690.613 & .605 & 36.804 & $.000^{\mathrm{b}}$ \\
\hline & Residual & 450.348 & & & \\
\hline & Total & 1140.962 & & & \\
\hline
\end{tabular}

a. Dependent Variable: Digital Competence

b. Predictors: (Constant), Individuals and Institutional values

Table 7 indicates that the regression model predicts the dependent variable (Digital competence) significantly well. Looking at the "Regression-a" row and then "Sig." column. This indicates the statistical significance of the regression model that was run. Here, $p<$ 0.001626 , which is less than 0.05, and it indicates that, overall, the regression model statistically significantly predicts the outcome variable (i.e., it is a good fit for the data). Then "Regression-b" under the "Sig." column, indicates the statistical significance of the regression model that was run. Here, $p<0.000003$, which is less than 0.05 , and indicates that, overall, the regression model statistically significantly predicts the outcome variable (i.e., it is a good fit for the data). R-square (from the model summary) for individual values is .34 (34.4\%) compared to R-square for institutional values is .605 (60.5\%), implying that, institutional values have a higher degree of correlation to teachers' digital competence levels as compared to individual values. Therefore, institutional values such as; curriculum design and development, ICT policies, ICT structures and leadership styles have a greater influence on teacher educators' technology knowledge and skills than individual values.

\subsection{Discussions}

\section{a. Hypothesis One}

Study findings are in line with what previous researchers found out that, individual values such as; level of education, teaching experience, attitude or belief and disciplinary background have been believed to positively associate with teacher educators' digital skills and knowledge. Previous studies indicate that, teaching experience influences positively technology knowledge and skills. For example, Graham (2011) found out that, implementing effective teaching with technology integration requires changes in teachers' beliefs. Donnelly, McGarr \& O'Reilly (2011), found out that, ICT integration outcomes in the learning and teaching contexts are reliant to a significant degree on what teachers do and think. According to Yusuf (2005) in Boakye (2013), teaching experience was found to influence the use of technologies by lecturers in teaching, and it is based on the assumption that, lecturers' willingness to apply technologies in teaching increases with teaching experience. As teachers explore numerous teaching approaches overtime, they are able to recognize and also accept technology-oriented approaches as being fundamental in teaching. Similarly, teaching experience is said to increase with effectiveness of teaching using technology (Win, 2002) in Boakye (2013). 
Study findings indicated that there is significant difference teacher educators' digital competence and teaching experience in The School of Education. However, these differences were based on the years spent in teaching, although this sometimes may not be true because by teaching experience we basically refer to actual teaching, there are individuals who have spent so many years in the system, but doing more of administrative work like; Head of Department, Deans coordinators of different activities, in that their actual exposure to teaching might have been limited a bit. Win (2002) found out that, lecturers' level of education influences their ability to teach using technologies.

\section{b. Hypothesis Two}

Tezci (2011) like the study results also found out that, institutional culture is a key in contributing to the development of ICT knowledge and skills. This research considered the following values: curriculum design and development, ICT policies, ICT structures and Leadership styles and the study results showed that all these aspects were rated very highly as being so fundamental in influencing teacher educators' technology knowledge and skills. Along the same line, Tosun \& Barişusing (2011:223) indicated that universities which want to reposition themselves in the market, they must have a strategic plan which clearly indicates how technology integration should be done, and this arrangement must be in line with the teaching curriculum. Malakia, J \& Cloneria, J (2018) aligns with that of McGarr (2009) which indicates that, the proliferation of ICT in society aid the transition from teaching ICT as a discrete informatics subjects into viewing ICT as a technological approach for learning across the curriculum. Again, Aguti (2016) emphasizes that in an effort to promote ICT integration, changes in the curricula must correspond to assessment. Foley \& Ojeda (2008) in Waycott, Bennett, Gregor, Dalgarno, \& Gray (2010) indicated that, the limited use of educational technologies in university teaching is due to limitations in national and institutional policies and management practices about ICT integration. Universities such as Makerere University where teacher training is given priority must assess existing weak ICT implementation policies so that full utilization of ICT in teaching is realized.

It must be noted that, while in a leadership position, it is time for learning from others and so, leadership is highly placed in social constructivist framework because it also encourages learning from one another as a result of continuous social interactions with the different individual characters. Singh (2015) found out that transformational leaders have a significant influence on achievement of goals. In a related development, the analysis of Bateh and Heyliger (2014) also indicated that faculty members who identified transformational leadership as dominant had increased performance. Again, Aunga, and Masare (2017) in Arusha District also revealed that, transformational leadership style focused on effect of leadership styles a direct and positive connection between the use of and teachers' performance. Teachers' performance at work involves use of appropriate teaching methods such as application of ICTs to simply learning. So, innovative use of technology in teaching is influenced by leadership style, since leadership styles such as transformational promotes teachers' creativity.

\section{Conclusion}

From the discussion, the following conclusions were drawn as per each hypothesis;

1. Individual values such as; level of education, teaching experience, attitude or belief and disciplinary background have a significant positive influence on teacher educators' technology knowledge and skills. 
2. Institutional values such as; curriculum design and development, ICT policies, ICT structures and Leadership styles have a significant positive influence on teacher educators' technology knowledge and skills.

\section{Recommendations}

1. The School of Education should develop an evaluative instrument to regularly assess the extent to which ICTs have promoted teaching and learning in the different Departments per subject and the Heads of Department should make a follow up on this, so that teacher trainers become confident users of ICTs in teaching and learning.

2. The need for innovative teaching in teacher training calls for a change in leadership styles, therefore, Makerere University administrators should change their leadership styles. Transformational leadership style according to the study results is the most suitable approach if we are to promote teacher educators' technology knowledge and skills.

\section{References}

Aguti, J. (2016). Common Frameworks on ICT in ED Teacher Training: Digitally Competent Teachers. UNESCO Headquarters, Paris.

Aunga, D.A. O. and Masare, O. (2017) Effect of leadership styles on teacher's performance in primary schools of Arusha District Tanzania. International Journal of Educational Policy Research and Review Vol.4 (4), pp. 42-52 April, 2017.

Bergquist, W. \& Pawlak, K. (2008). Engaging the Six Cultures of the Academy. San Francisco: Jossey-Bass.

Boakye Afia (2013). Factors associated with use of emerging technologies in teaching and research in Ghanaian public universities. African Journal of Education and Technology, Volume 3 Number 1 (2013), pp. 76-85.

Buabeng-Andoh, C. (2012b). Factors influencing teachers' adoption and integration of information and communication technology into teaching: A review of the literature. International Journal of Education and Development using Information and Communication Technologies, 8(1), 136-155.

Czerniewicz, L. \& Brown, C. (2007). Disciplinary differences in the use of educational technology. In D. Remenyi,ICEL 2007: 2nd International Conference on e-Learning. New York. 28-29 June. 117-130.

Edward, Y. R., \& Calen. (2020). The Influence of Organizational Culture, Training and Communication toward Employee Performance in PT Multi Jaya Samudera. SLASAT, 5(3), 40-50. https://doi.org/10.33258/siasat.v5i3.68

Gregory S. C. Hine (2013). The importance of action research in teacher education Programs. Issues in Educational Research, 23(2): Special Issue. The University of Notre Dame Australia.

Jo Shan (2013) ICT in Education: A Critical Literature Review and Its Implications. International Journal of Education and Development using Information and Communication Technology (IJEDICT), 2013, Vol. 9, Issue 1, pp. 112-125.

Ling Li (2014). Towards a cultural framework to understand teachers' ICT adoption: a case study. Educate Vol. 14, No. 2, 2014, p. 29 43. (http://www.educatejournal.org).

Phillips, S. C.-, Deb Proshad Halder, Serlange Campbell, \& Daneil Phillips. (2020). Cross Cultural Differences in Cognition: A Study on How Culture Affects the Way We Think. SLASAT, 5(3), 9-15. https://doi.org/10.33258/siasat.v5i3.64

Sahlberg, P., \& Boce, E. (2010). Are teachers teaching for a knowledge society? Teachers and Teaching: Theory and Practice, 16(1), 31-48. 
Shamaki, E. B. (2015) Influence of Leadership Style on Teacher's Job Productivity in Public Secondary Schools in Taraba State, Nigeria. Journal of Education and Practice Vol.6, No.10, 2015

Singh, K. (2015). Leadership Style and Employee Productivity: A Case Study of Indian Banking Organizations. Journal Of Knowledge Globalization, 8(2), 39-67.

Sloan, T. (2013) Distributed Leadership and Organizational Change. Implementation of a Teaching Performance Measurehttps://doi.org/10.1080/1547688X.2013.751313

Teo, T. (2012). Examining the intention to use technology among pre-service teachers: an integration of the technology acceptance model and theory of planned behavior. Interactive Learning Environments, 20(1),3-18.

Tezci, E. (2011). Turkish primary school teachers' perceptions of school culture regarding ICT integration. Educational Technology Research and Development, 59(3), 429-443.

Tosun, N. \& Barişusing, M.F., (2011:223), "Information and communications technologies in school improvement", The Turkish online Journal of Education Technology $10(1), 223-230$.

UNESCO (2000). The Dakar Framework for Action. UNESCO: Paris.

Wu FY, Shiu C (2009): The Relationship between Leadership Styles and Foreign English Teachers Job Satisfaction in Adult English Cram Schools: Evidences in Taiwan,' the J. Ame. Acad Bus., Cambridge 14(2). 